\title{
BONE REPAIR INDUCED BY BONE MORPHOGENETIC PROTEIN IN ULNAR DEFECTS IN DOGS
}

\author{
OLLE S. NILSSON, MARSHALL R. URIST, EDGAR G. DAWSON, THOMAS P. SCHMALZRIED, G. A. M. FINERMAN
}

\author{
From the Bone Research Laboratory, University of California, Los Angeles
}

\begin{abstract}
In dogs, resection of a length of the ulna equal to twice the diameter of the mid-shaft leaves a defect which consistently fails to unite. In response to an implant of $100 \mathrm{mg}$ of bovine bone morphogenetic protein (BMP), the defect becomes filled by callus consisting of fibrocartilage, cartilage and woven bone within four weeks. The cartilage is resorbed and replaced by new bone in four to eight weeks. Woven bone is then resorbed, colonised by bone marrow cells and remodelled into lamellar bone. Union of the defect is produced by 12 weeks. Control defects filled with autogeneic cortical bone chips unite after the same period.

In regeneration induced by bone morphogenetic protein (BMP) and in repair enhanced by bone graft, union depends upon the proliferation of cells within and around the bone ends. Our working hypothesis is that BMP induces the differentiation of perivascular connective tissue cells into chondroblasts and osteoprogenitor cells and thereby augments the process of bone regeneration from the cells already present in the endosteum and periosteum.
\end{abstract}

For over a half century (Key 1934), the resection of $2.5 \mathrm{~cm}$ of the diaphysis of the dog's ulna has been employed in research on bone repair and osteogenesis. Key wrote "the diameter of the bone roughly determines the (maximum) length of the section which can be removed from the shaft of this bone and not result in non-union. In adult dogs this length is $1 \frac{1}{2}$ times the diameter". Key observed that the insertion of boiled bone, bone powders, calcium salts and other non-viable fillers into the defect produced non-union, while an autogeneic bone graft generally produced solid union.

Heiple. Chase and Herndon (1963) used the same model to investigate the process of regeneration in defects of over twice the diameter of the bone and demonstrated that autogeneic bone was superior to both allogeneic bone (whether this was aseptically collected, fresh or freeze-dried, or sterilised by irradiation) and to demineralised bone matrix. Bos et al. (1983) revised Heiple's scoring system, and suggested that tissue typing would improve the results of allogeneic transplants. Goldberg et al. (1984) applied the revised scoring system to investigate the effects of immunosuppression after

O. S. Nilsson. MD, Fulbright Travelling Scholar

Karolinska Institute. Department of Orthopaedic Surgery, Karolinska Hospital. S-10401 Stockholm. Sweden.

M. R. Urist. MD. Professor of Surgery (Orthopaedics)

E. G. Dawson. MD. Professor

T. P. Schmalzried. Resident

G. A. M. Finerman. Professor

University of California, Los Angeles, Bone Research Laboratory.

Rehabilitation Center. RM A3-34, 1000 Veteran Avenue, Los Angeles, California 90024. USA.

Requests for reprints should be sent to Professor M. R. Urist.

( 1986 British Editorial Society of Bone and Joint Surgery $0301620 \times 86.4114 \$ 2.00$ the grafting operation and concluded that, although infection was a significant complication, allograft incorporation was more complete at 26 weeks in immunosuppressed animals than in untreated controls. Burchard and Enneking used massive bone grafts in resection defects in the dog's fibula and gave a detailed description of the interdigitation of host and donor tissues. They affirmed the superiority of autogeneic bone over all other grafts, derivatives and substitutes (Burchardt, Busbee and Enneking 1975; Burchardt, Glowczewskie and Enneking 1977; Burchardt and Enneking 1978; Burchardt et al. 1978).

Clinical studies must be concerned not just with repair of defects in normal bone but also with abnormal bone such as the sclerotic bone ends resulting from old infections, insufficient immobilisation, or mechanically unsatisfactory internal fixation, and with the result of malignancy. The consensus of opinion is that transplantation of autogeneic bone is the best treatment. However, the failure rate of autografting for un-united fractures and other bone defects is about 30\% (Burwell 1969). This high rate of failure motivates our continued research on bone defects in dogs, with experiments to compare autogeneic bone transplants with implants of bone morphogenetic protein (BMP). BMP is a tissuespecific parameter of bone metabolism in health and disease (Urist and Hudak 1984), and has been discussed in a number of papers (Urist, Jurist, Dubuc and Strates 1970; Urist et al. 1982; Urist, DeLange and Finerman 1983; Urist and Hudak 1984; Urist et al. 1984, 1985). A survey of this work with the findings of radioimmunoassay of BMP, is given in Urist and Hudak (1984).

Human BMP is currently being used in preliminary clinical trials in patients with one or more failed bone 
graft operations or with non-union which has failed to respond to prolonged electrical stimulation. Bovine rather than human BMP is used in our experiments on dogs because of the limited availability of freshly excised human or canine bone for chemical extraction by present methods (Urist et al. 1982, 1983, 1984). Since bovine BMP cross-reacts immunologically with canine and human BMP, and induces heterotopic bone formation in comparable doses in muscle pouches in mice, it is useful for comparative animal research.

\section{MATERIALS AND METHODS}

BMP is prepared by chemical extraction from the combined intracellular and extracellular elements of cortical bone. Its amino-acid sequence and structure are under investigation in both academic and industrial laboratories.

BMP has not yet been completely purified but the following characteristics have been published: it is an acidic protein, pI $5.0 \pm 0.2 ; M_{\mathrm{r}} 18.5$ (bovine BMP), $M_{\mathrm{r}}$ $17.0 \pm 0.5$ (human BMP). It is insoluble in aqueous media under dissociative formation of complexes with $\mathrm{Ca}^{++}$and matrix $\gamma$-carboxyglutamic acid-containing protein, $M_{\mathrm{r}} 14 \mathrm{~K}$. It is insoluble in acetone, absolute alcohol, chloroform, methanol and Triton X-100. It is disulphide-bonded, and is inactivated by heat $>70^{\circ} \mathrm{C}$, deamination in $\mathrm{HNO}_{3}, \beta$-mercaptoethanol reduction, lathyrogens, penicillamine and ultrasound. BMP binds to hydroxyapatite. It is resistant to collagenase, chondroitinases A, B and C, amylase, neuraminidase, hyaluronidase, alkaline phosphatase, acid phosphatase, chymopapain, tyrosinase, and thermolysin. It retains its activity after limited proteolysis with pepsin or trypsin.

BMP was extracted and partially purified from the long bones of young steers by the methods described in detail in the papers listed above. Briefly, finely ground fresh cortical bone was demineralised, defatted, and the non-collagenous proteins solubilised by urea. These proteins were further purified by differential precipitation and resolubilisation using urea or guanidine hydrochloride. The process ends with a partly purified, waterinsoluble protein preparation, containing about 30 protein species, which consistently has high biological activity in terms of bone induction, and contains molecules that act as carriers for, and modifiers of. BMP. The carrier proteins for BMP consist of an aggregate of matrix $\gamma$-carboxyglutamic acid-rich protein, histone $2 \mathrm{~B}$, and calmodulin (Urist et al. 1984).

Gelatin capsules were packed with $100 \mathrm{mg}$ samples of BMP while control capsules were packed with $100 \mathrm{mg}$ samples of bovine serum albumin (BSA). The capsules were gas sterilised in ethylene oxide and stored in plastic envelopes in sterile containers.

Nineteen adult mongrel dogs weighing 18 to $30 \mathrm{~kg}$ were conditioned for six weeks by vaccinations and observed for signs of disease. Segmental resection of part of the ulna was performed bilaterally as described by Key (1934) and Heiple et al. (1963). The ulna was approached by blunt dissection through a $6 \mathrm{~cm}$ posterolateral incision, and exposed extraperiosteally. A segment measuring twice the diameter of the bone (about $2.5 \mathrm{~cm}$ ) was resected with its periosteum.

In 10 dogs (Group A), a capsule containing $100 \mathrm{mg}$ of partially purified bovine BMP was implanted into the defect in the ulna on one side, and a control capsule of $100 \mathrm{mg}$ of BSA was similarly implanted in the contralateral limb. In the nine dogs of Group B, the defect on one side was packed with resected pieces of ulna cut into 2 to $3 \mathrm{~mm}$ fragments to provide autograft controls for the contralateral nine ulnar defects which were implanted with BMP. At all sites soft tissues and muscle attachments were repaired to retain the capsule or bone graft securely in place. The controls and BMP were implanted on alternating sides in successive dogs. Postoperatively, intramuscular injections of cefazolin sodium (Ancef) $500 \mathrm{mg}$ daily were given for three days.

Lateral radiographs were taken of each limb at two weeks, and at one, two, three, and four months after operation to follow the healing process at the resection sites. In Group A, three dogs were killed at one month, three at two months, and four at three months. In Group B, two were killed at one month, two at two months, two at three months and three after four months. To improve visualisation of new bone deposits, the ulnae were dissected free of muscle and radiographs were taken in two planes. The area of the graft and its surrounding bone was then excised, decalcified, sectioned and stained with haematoxylin, eosin and azure II. Histomorphometric findings were recorded for sections taken parallel to the longitudinal axis of the bone, and extending over the entire length of the defect. The repair process was graded by the method of Bos et al. (1983) as modified from that of Heiple et al. (1963). The scoring system is given in Table I.

In Group A the area of the callus was estimated by planimetry on lateral radiographs, and was expressed for

Table I. Histomorphometric grading of the repair of the ulnar defect

\begin{tabular}{|c|c|c|}
\hline & & Score \\
\hline Union & $\begin{array}{l}\text { No sign } \\
\text { Fibrous } \\
\text { Fibrocartilaginous } \\
\text { Bony } \\
\text { Complete, with trabecular and cortical } \\
\text { bone }\end{array}$ & $\begin{array}{l}0 \\
1 \\
2 \\
3 \\
4\end{array}$ \\
\hline Callus & $\begin{array}{l}\text { None } \\
\text { Small amount } \\
\text { Moderate amount } \\
\text { Profuse } \\
\text { Bridging }\end{array}$ & $\begin{array}{l}0 \\
1 \\
2 \\
3 \\
4\end{array}$ \\
\hline Bone marrow & $\begin{array}{l}\text { None in resected area } \\
\text { Beginning to appear } \\
\text { Present in more than half of the defect } \\
\text { Complete colonisation by red marrow } \\
\text { Mature fatty marrow }\end{array}$ & $\begin{array}{l}0 \\
1 \\
2 \\
3 \\
4\end{array}$ \\
\hline
\end{tabular}



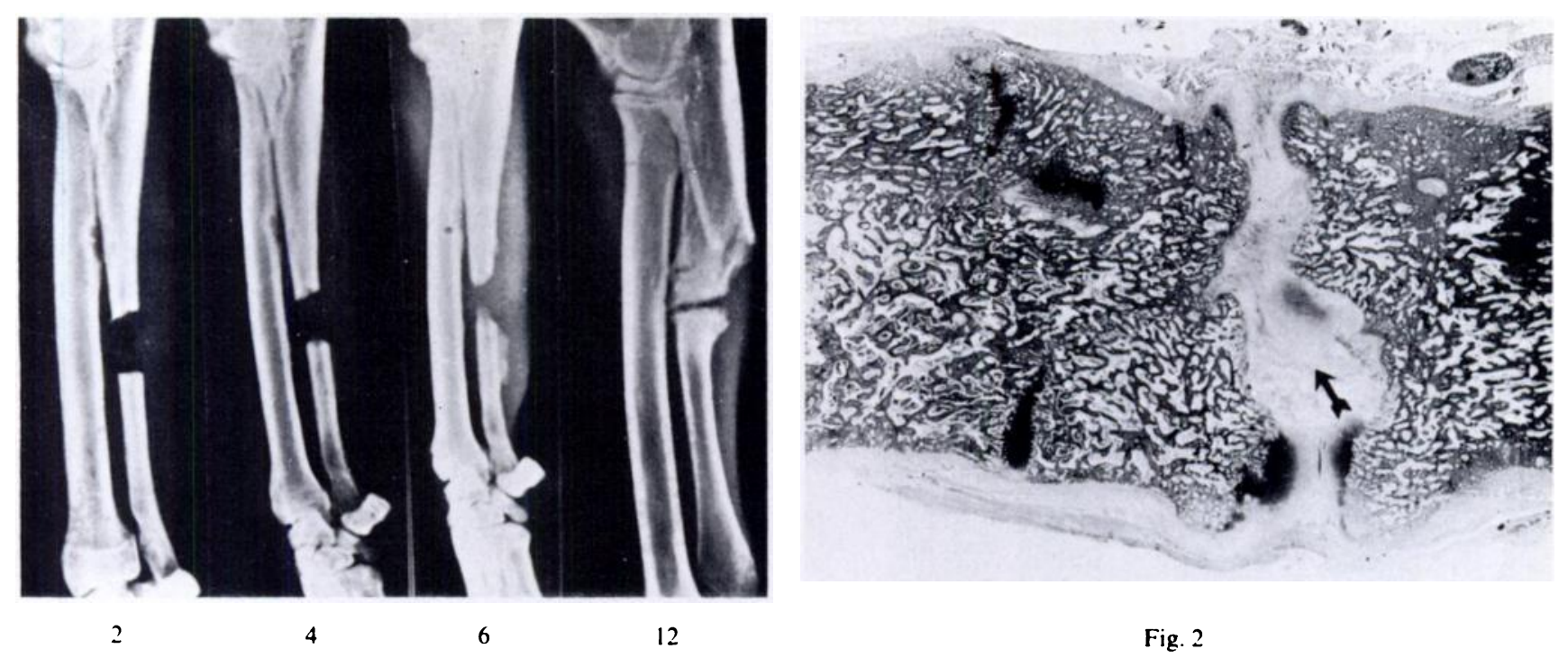

Fig. 2

Fig. 1

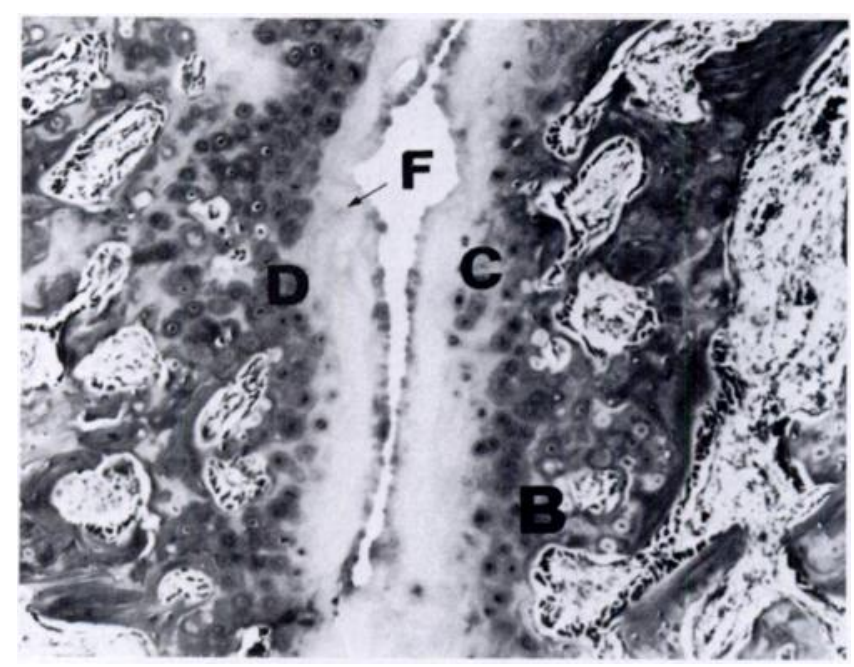

Fig. 3

Figure 1 Radiographs to show control defects in a dog's ulna at 2, 4.6 and 12 weeks after resection and implantation of bovine serum albu$\min$. A pseudarthrosis has developed. Figure 2 Photomicrograph of the pseudarthrosis seen in Figure 1, 12 weeks after resection $(\mathrm{H} \& \mathrm{E}, \times 5)$. Figure 3 - High-power view of the pseudarthrosis cavity 12 weeks after resection. $F$, fibrinoid degeneration: $C$, cartilage; $D$. chondro-osseous tissue; $B$, subchondral bone $(\mathrm{H} \& \mathrm{E}, \times 40)$.

each time interval as a ratio between the area in defects treated with BMP and that in BSA-treated defects. The percentage of the defects which had been bridged by callus after each time interval was noted. Only when mineralised bone tissue bridged the entire defect was the ulna regarded as healed. In Group B, in which autogeneic bone had been transplanted to the control side, the volume of callus filling spaces between grafted bone fragments was determined histologically.

All grading procedures and planimetric estimations were performed independently by two observers. Wilcoxon's rank sum test for paired observations was used to determine the statistical significance of the difference in scores between the BMP-treated defects and the two control groups, in each case comparing the BMPtreated defect with its contralateral control.

\section{RESULTS}

The dogs tolerated the operations well, weight-bearing began within four days; there were no infections nor any stress fractures of the radius. The control defects of Group A, implanted with BSA, invariably developed a pseudarthrosis (Figs 1,2 and 3). The control defects of Group B, implanted with autogeneic bone chips, were bridged with new bone within two to three months in seven of nine dogs. The side treated with BMP in both groups developed a large calcified callus, seen radio- 
graphically in some dogs as early as two weeks and in all dogs within one month of operation; by 12 weeks the gap was completely bridged by new bone (Figs 4 to 7). The relative areas of bony callus in BMP and BSA-treated defects and the percentages of the defects bridged by radioopaque callus are shown in Table II. The BMP-healed defects had from four to nearly six times larger planimetric volumes of callus. The highest ratio was noted as early as one month. Sequential radiographs of defects implanted with BMP or with autograft showed comparable results in terms of the number of defects enveloped in new bone at various intervals (Table III). However, in two dogs the autografts had failed to unite to one or other bone end after 12 weeks, while the contralateral BMPimplanted defect showed solid union (Figs 8 and 9).

Healing was rapid in all 19 defects treated with BMP, bridging by a large fusiform bony callus generally being complete by two months (see Fig. 1, Table II). The

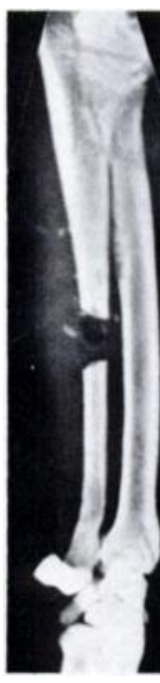

2

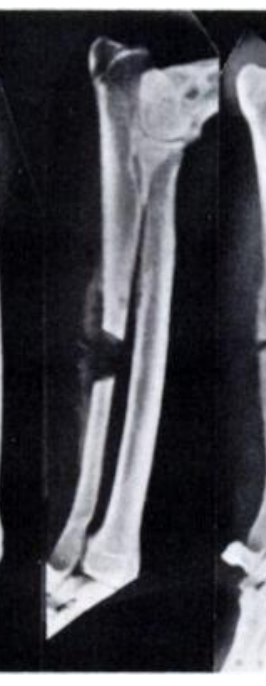

4

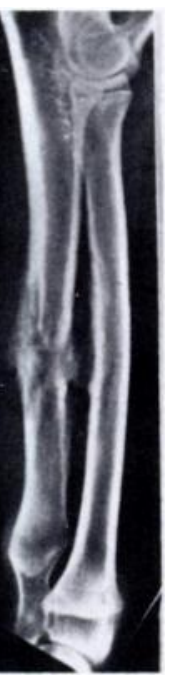

12

Fig. 4

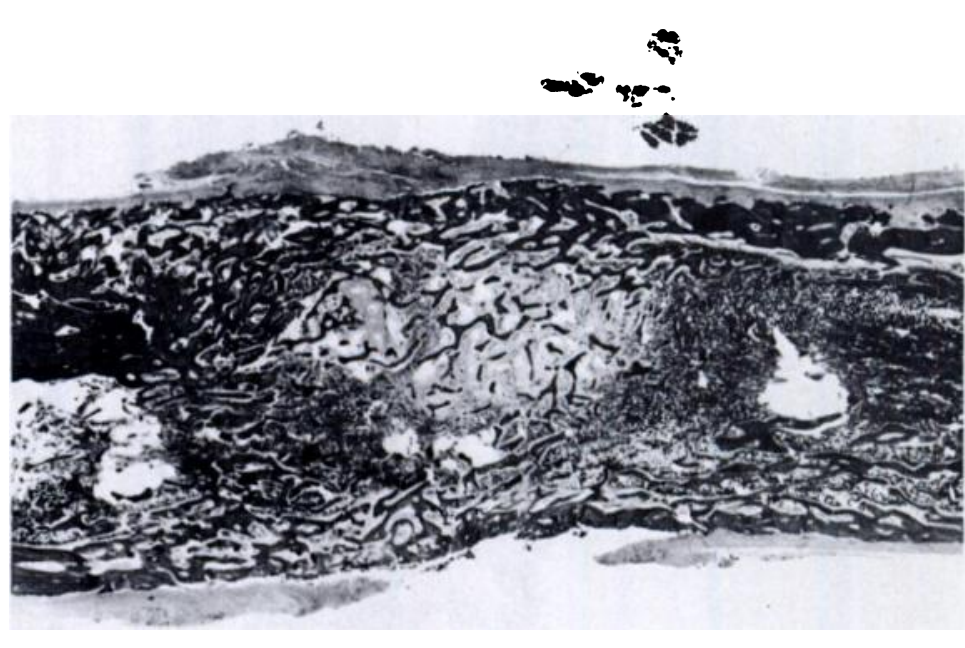

Fig. 5

Figure 4 A typical series of radiographs, taken after 2, 4,6 and 12 weeks, of ulnar resections implanted with $100 \mathrm{mg}$ of bovine BMP, showing bridging of the defect by mineralised callus. Figure 5 Photomicrograph of the healed bone defect, seen in Figure 4, 12 weeks after implantation of $100 \mathrm{mg}$ of BMP. Note the reconstruction of lamellar bone on the periphery and of trabecular bone and bone marrow in the central regions $(H \& E, \times 5)$.

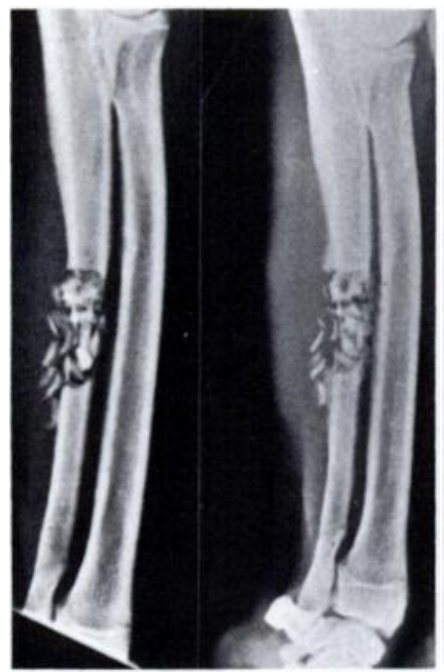

AUTOGRAFT

Fig. 6

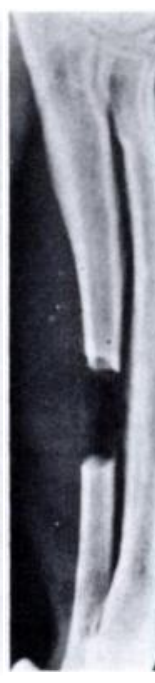

BMP

Fig. 7

MP

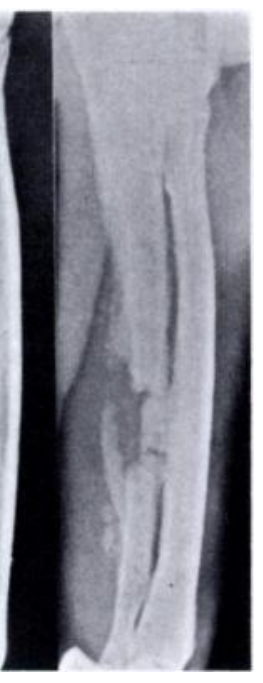

Radiographs of resection defects, soon after operation and four weeks later.

Figure 6 - After autogeneic cortical bone transplant. Figure 7 - After implantation of $100 \mathrm{mg} \mathrm{BMP}$. Note the relatively large volume of new bone in the external callus after BMP.

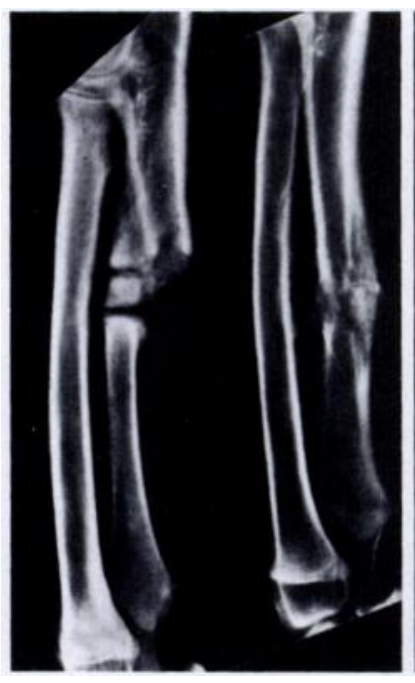

GRAFT

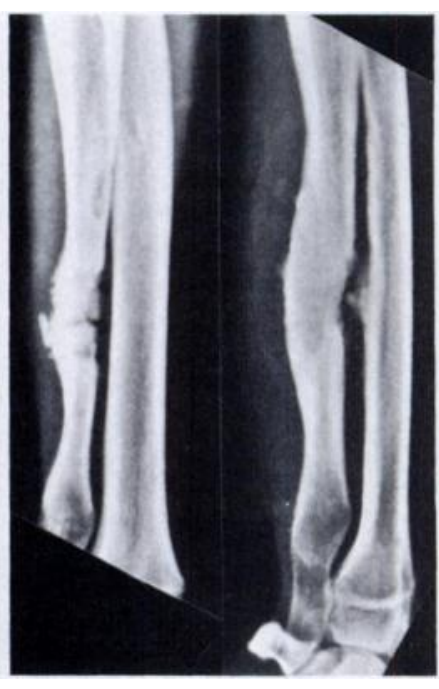

GRAFT
Pairs of radiographs from single dogs 12 weeks after operation. Figure 8 - The autograft had united with only the proximal bone end, while the defect in which BMP was implanted is completely bridged by new bone. Figure 9 - After 12 weeks there is non-union of the ulnar defect implanted with cortical bone chips. The contralateral ulnar defect was implanted with BMP and is enveloped with, and bridged by, new bone. 
spindle of tissue bridging the defect by one month consisted of fibrocartilaginous callus, with woven bone enveloping partly uncalcified and partly calcified cartilage. Between two and three months the woven bone was being remodelled and replaced by lamellar bone. In contrast, autografted defects at that stage showed relatively small bands of woven bone and very little cartilage in the spaces between particles of compact bone.

The results of histological and histomorphometric analyses at various stages of healing are given in Table IV and a section of the BMP-induced bone formation at three months (Fig. 5) demonstrates its organised nature.
The defect is filled with a central spherical mass of lacy trabecular bone and interstitial mesenchymal tissue, surrounded by a shell of densely woven cancellous bone and red bone marrow. The continuity of the ulnar cortex has been restored by new lamellar bone. The new bone deposits separated the medullary cavity of the ulna into two marrow cavities, one proximal and one distal to the site of the defect.

In the seven defects in which autografts had produced union, the total histological scores were about the same as those produced after implants of BMP. The scores in BSA-implanted controls were less than those

Table II. Results of radiomorphometry of Group A defects

\begin{tabular}{|c|c|c|c|c|c|c|}
\hline \multirow{2}{*}{$\begin{array}{l}\text { Time since } \\
\text { surgery } \\
\text { (months) }\end{array}$} & \multirow[b]{2}{*}{ Number } & \multirow{2}{*}{$\begin{array}{l}\text { Ratio of area } \\
\text { of new bone: } \\
\text { BMP/control }\end{array}$} & \multicolumn{2}{|c|}{$\begin{array}{l}\text { Percentage of } \\
\text { defect bridged }\end{array}$} & \multicolumn{2}{|c|}{$\begin{array}{l}\text { Number of defects } \\
\text { bridged by new bone }\end{array}$} \\
\hline & & & BMP & BSA control & $\mathbf{B M P}$ & BSA control \\
\hline 1 & 10 & $5.5 \pm 1.6$ & $77 \pm 15$ & $39 \pm 15$ & 2 & 0 \\
\hline 2 & 7 & $5.1 \pm 1.5$ & $94 \pm 6$ & $57 \pm 12$ & 5 & 0 \\
\hline 3 & 4 & $4.5 \pm 1.2$ & 100 & $76 \pm 13$ & 4 & 0 \\
\hline
\end{tabular}

Ratios and percentages are given as mean \pm s.d.

BMP, bone morphogenetic protein

BSA, bovine serum albumin

Table III. Results of radiomorphometry of Group B defects

\begin{tabular}{llllll}
$\begin{array}{lllll}\text { Time since } \\
\text { surgery } \\
\text { (months) }\end{array}$ & Number & $\begin{array}{l}\text { Percentage of } \\
\text { defect filled } \\
\text { with callus } \\
\text { after BMP }\end{array}$ & \multicolumn{2}{l}{$\begin{array}{l}\text { Number of defects } \\
\text { bridged by new bone }\end{array}$} \\
\hline 1 & 9 & $69 \pm 10^{*}$ & BMP & Autograft \\
\hline 2 & 7 & $92 \pm 5^{*}$ & 0 & 0 \\
\hline 3 & 5 & 100 & 6 & 5 \\
4 & 3 & 100 & 5 & 5 \\
\hline
\end{tabular}

*mean \pm s.d.

Table IV. Results of histomorphometric grading of the bone healing of ulnar defects treated in three ways

\begin{tabular}{|c|c|c|c|c|c|}
\hline \multirow[b]{2}{*}{ Treatment } & \multirow{2}{*}{$\begin{array}{l}\text { Time since } \\
\text { surgery } \\
\text { (months) }\end{array}$} & \multirow[b]{2}{*}{ Number } & \multicolumn{3}{|c|}{ Grading scores } \\
\hline & & & $\begin{array}{l}\text { Histological } \\
\text { union }\end{array}$ & $\begin{array}{l}\text { Callus } \\
\text { formation }\end{array}$ & $\begin{array}{l}\text { Colonisation of } \\
\text { bone marrow }\end{array}$ \\
\hline BMP (Groups A and B) & $\begin{array}{l}1 \\
2 \\
3 \\
4\end{array}$ & $\begin{array}{l}5 \\
5 \\
6 \\
3\end{array}$ & $\begin{array}{l}1.0(1) \\
2.8(2-3) \\
3.3(2-4) \\
3.7(3-4)\end{array}$ & $\begin{array}{l}1.6(1-2) \\
3.4(3-4) \\
3.7(2-4) \\
4.0(4)\end{array}$ & $\begin{array}{l}1.0(1) \\
1.4(1-2) \\
3.2(2-4) \\
3.3(3-4)\end{array}$ \\
\hline BSA (Group A control) & $\begin{array}{l}1 \\
2 \\
3\end{array}$ & $\begin{array}{l}3 \\
3 \\
4\end{array}$ & $\begin{array}{l}1.0(1) \\
1.3(1-2) \\
1.3(1-2) \\
p<0.02\end{array}$ & $\begin{array}{l}1.0(1) \\
1.7(1-3) \\
2.3(1-3) \\
p<0.01\end{array}$ & $\begin{array}{l}0.3(0-1) \\
0.7(0-1) \\
0.5(0-1) \\
\mathrm{p}<0.01\end{array}$ \\
\hline $\begin{array}{l}\text { Autogeneic cortical } \\
\text { bone chips (Group B) }\end{array}$ & $\begin{array}{l}1 \\
2 \\
3 \\
4\end{array}$ & $\begin{array}{l}2 \\
2 \\
2 \\
3\end{array}$ & $\begin{array}{l}1.0(1) \\
2.5(2-3) \\
2.0(2) \\
3.0(2-4) \\
\text { NS }\end{array}$ & $\begin{array}{l}1.0(0-2) \\
1.0(1) \\
2.0(2) \\
3.3(2-4) \\
p<0.02\end{array}$ & $\begin{array}{l}0.5(0-1) \\
0.5(0-1) \\
1.5(1-2) \\
1.3(1-2) \\
\text { NS }\end{array}$ \\
\hline
\end{tabular}

Scores for each group are mean (range) derived as given in Table I

Statistical analysis by Wilcoxon's rank sum test for paired samples

BMP-treated defects were compared, for each parameter, with the contralateral control

NS, no significant difference between groups 


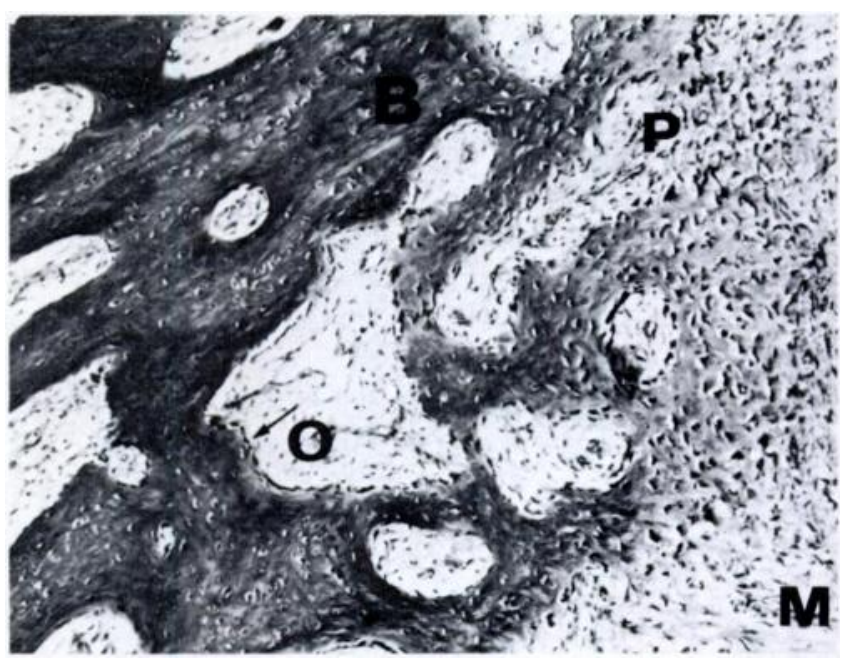

Fig. 10

High-power photomicrograph of the bone which develops after implantation of BMP. Figure 10 - Two months after implant $(\times 50)$. Figure 11 - To show appositional bone formation in remodelling bony callus, three months after implantation of BMP $(\times 50)$. Figure 12 Enchondral trabecular bone showing cores of unabsorbed cartilage in bone three months after implantation of $\operatorname{BMP}(\times 100)$. The arrow indicates an appositional cement line. $M$, mesenchymal cells; $P$, osteoprogenitor cells; $O$, osteoblasts; $B$, bone; $L$, lamellar bone; $R$, bone marrow; $C$, remnants of unabsorbed cartilage; $V$, capillary.
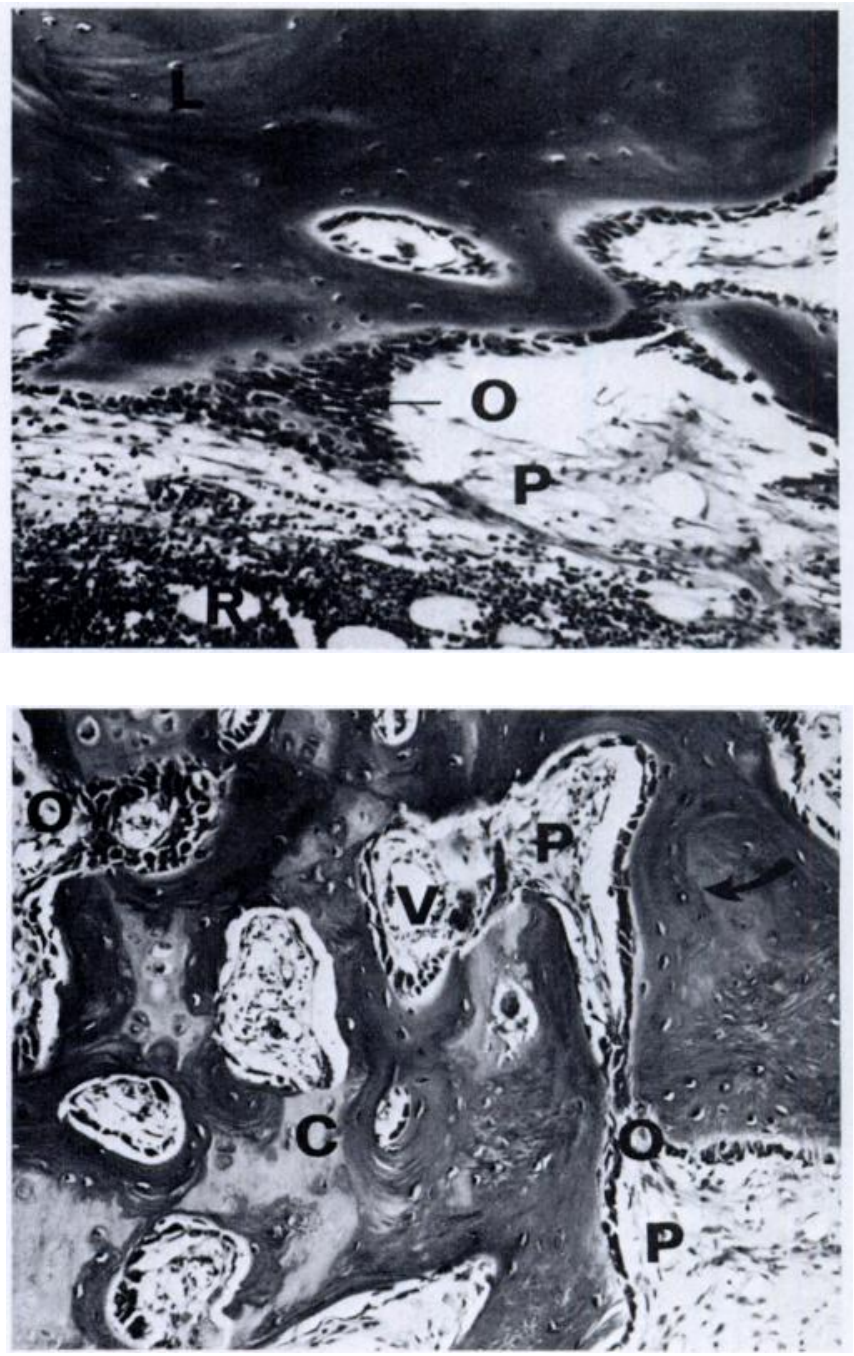

myelopoietic cells. There were no chronic inflammatory cells, plasma cells, focal collections of small round cells, or any other indication of an immunogenic reaction. No remnants of the implanted BMP were found in the host bed at any time from one to three months after implantation (Figs 10 to 12).

\section{DISCUSSION}

The results show that, without any bone graft, an implant of BMP induces complete regeneration of a segmental diaphyseal defect. Control defects implanted with BSA formed a pseudarthrosis while the BMP-implanted defects showed an exuberant regenerative process, with union almost invariably occurring in less than three months. The rate of restoration of bone continuity is about the same as in the autografted control defects. The main difference here was in the significantly larger volume of new bone formed in BMP-induced regeneration. Because the bone formation induced by BMP extends from the periosteum surrounding the bone ends and from the marrow cavity, the cellular elements and vascular system of the host tissues are an integral part of the induced response.

pools of haemopoietic bone marrow tissue. This marr included the full range of normal erythropoietic and 
To avoid ambiguity in evaluating BMP, two control systems are essential. In the first group (A), bovine serum albumin was used as a xenogeneic protein control. Bovine BMP is also a xenogeneic protein but in a single dose of $100 \mathrm{mg}$ ( 3 to $5 \mathrm{mg} / \mathrm{kg}$ body weight) it is tolerated by bone tissues as well as is the albumin, except that the latter has no inductive properties. The Group A controls demonstrate the limits of spontaneous regeneration and the volume of callus produced as a reaction to injury. These controls also corroborate the observations of Key (1934) and Heiple et al. (1963), that non-union consistently follows an ungrafted $2.5 \mathrm{~cm}$ defect in the ulna. For reasons not yet apparent, some defects show a hypertrophic pattern of non-union with the rapid and abundant formation of external callus, while others develop an atrophic non-union. These two forms of non-union were seen in the BSA-implanted controls with equal incidence. There was no evidence of any systemic effect of BMP acting on a contralateral control defect.

Previous observations on bone induced by BMP in muscle pouches demonstrate that the target cell may be a perivascular connective tissue cell (pericyte) and that BMP may be angiogenetic in action (Lindholm and Urist 1980; Urist et al. 1982). Cells with osteogenetic competence are classified as pericytes, perisinusoidal stroma cells, adventitial cells, or as mesenchymal-type cells (Burwell 1963; Lindholm and Urist 1980; Nathanson and Hay 1980; Tavassoli and Yoffey 1983). Observations on marrow transplants to heterotopic sites in tissue culture demonstrate differentiation of cartilage in vitro and cartilage and bone in vivo in response to bone matrix (Lindholm and Urist 1980) or to implants of BMP (Tagaki and Urist 1982). In rodents, muscle-derived pericytes (Urist et al. 1983) and embryonic myoblasts (Nathanson, Hilfer and Searls 1978; Nathanson and Hay 1980; Nathanson 1983) are as responsive as marrowderived cells; but in dogs, non-human primates, and in man, marrow stroma-derived cells are by far the most readily induced to differentiate into osteoprogenitor cells.

Whether BMP may also stimulate the proliferation of osteoprogenitor cells, osteoblasts, or osteocytes is difficult to demonstrate because such cells are impossible to separate from pericytes and other perivascular cells. Periosteum is rich in capillaries and pericytes, and endosteum even more so.

Burwell $(1963,1969)$ and subsequently others investigating demineralised bone matrix implants (Lindholm and Urist 1980; Glowacki, Altobelli and Mulliken 1981; Velasco et al. 1983; Wittbjer et al. 1983; Einhorn et al. 1984) emphasise the key role of the bone marrow of the host bed in the incorporation of a bone graft. If the role of bone marrow were critical in the response to BMP, plugging the bone ends with bone wax should eliminate the target tissue, producing non-union after a BMP implant like that seen after a BSA implant. Takagi and Urist (1982) plugged the marrow cavities with an omega- shaped wire, across a $1.0 \mathrm{~cm}$ defect in rat femora; repair was seen only when bone marrow was implanted in the defect in addition to BMP. These observations also affirm the importance of the time-honoured practice of opening the marrow cavity of both bone ends in the operative treatment of non-union.

The experimental system applied here, using ulnar resection for the evaluation of bone grafts, also illustrates the dual action of the host bed and the BMPimplant in bone repair. The host bed contributes osteoprogenitor cells which are differentiated bone cells derived from periosteum, endosteum, and marrow stroma. The marrow stroma and surrounding soft tissues contribute a supplementary population of BMP-sensitive pericytes.

One very important factor in the incorporation of an autograft is close contact between the donor tissue and the host bed. The autogeneic bone chips were so tightly packed and well retained in the defect, that it was not possible to distinguish new bone derived from the autograft tissue from that derived from the host bed. The incorporation of autogeneic bone in the ulnar defect occurred within the same period of time as bone regeneration induced by BMP, but there was one grossly visible difference. The volume of the spindle of callus and the quantity of BMP-induced new bone was significantly greater than that produced by a cortical bone autograft. Moreover, in all nine dogs neither resorption nor remodelling of the cortical bone autograft was complete after three months, and union occurred in only seven of the nine dogs; there was non-union at one or the other end of the graft in two dogs. The defects that failed to unite by three months showed histological and radiographic signs of non-union, with sclerotic bone ends adjacent to an area of fibrocartilaginous tissue which extended across the entire width of the bone.

By contrast, in all 19 segmental defects implanted with BMP there were no instances of non-union and all defects were repaired by three months. Radiographs showed evidence of mineralising woven bone in these cases as early as two weeks, which was not seen with autografts. In most BMP-implanted defects, new bone bridged almost the entire defect by one to two months.

Histologically, BMP-induced deposits show osteoclastic and osteoblastic activity everywhere, indicative of remodelling and the conversion of woven bone into lamellar bone. There is most activity between two and three months after the implant. Concurrently, areas of remodelling bone were seen to be colonised by bloodborne marrow-derived cells. Thus, once it is deposited, the BMP-derived bone appears to recapitulate the developmental sequences of the embryonic growth of the original bone. Whether blood-borne elements enter into or contribute to the inductive process at an earlier stage is not known. Fundamental research is necessary on the mode of action of BMP including work on: mesenchymal cell receptor sites, limited proteolysis in the initial tissue 
response, delivery systems dependent upon supramolecular or inframolecular structure, the activity of serum BMP and anti-BMP, and many as yet undefined local and systemic factors associated with BMP metabolism.

The response to $100 \mathrm{mg}$ of partially purified bovine BMP which is described above differs from that to implants of whole demineralised bovine bone matrix in three important respects. First, BMP is cell-free, while cells form $15 \%$ of demineralised raw bone matrix, which also includes immunogenic collagenous and noncollagenous high molecular weight proteins from the donor tissue. Allogeneic (and especially xenogeneic) bone matrix incites an immune response involving reticulocytes, plasma cells and macrophages and is very slowly resorbed over a period of months or years. BMP is soluble in body fluids, and depending on the dose, is absorbed within a period of a few hours or days; a single exposure did not incite any detectable cell-mediated immune response. Secondly, BMP or an immunoreactive sub-unit of BMP is normally present in body fluids (Urist et al. 1985). It is therefore not a foreign substance within the host. Thirdly, the present method of detecting any systemic effect of BMP on bone regeneration is not conclusive. While the systemic effects of autogeneic, allogeneic, or xenogeneic BMP are not clear, locally induced bone formation has been proven to occur. Until more is known of the immunology of BMP, adverse immunological effects of xenogeneic proteins should be minimised by the use of a single exposure only, or by implanting only allogeneic or synthetic preparations comparable in purity to synthetic hormones. In any case, it is important to emphasise the point that all the bone formed in response to an implant of BMP is derived from the host; therefore it would not be expected to show such signs of late rejection as occur in response to nonautogeneic bone grafts.

\section{REFERENCES}

Bos GD, Goldberg VM, Powell AE, Heiple KG, Zika JM. The effect of histocompatibility matching on canine frozen bone allografts. $J$ Bone Joint Surg $[\mathrm{Am}]$ 1983;65 A:89-96.

Burchardt H, Busbee GA III, Enneking WF. Repair of experimental autologous grafts of cortical bone. J Bone Joint Surg [Am] 1975; 57 A:814 9 .

Burchardt H, Enneking WF. Transplantation of bone. Surg Clin North Am 1978:58(2):403-7.

Burchardt H, Glowczewskie FP, Enneking WF. Allogeneic segmental fibular transplants in azathioprine-immunosuppressed dogs. J Bone Joint Surg $[\mathrm{Am}]$ 1977:59 A:881 94.

Burchardt H, Jones H, Glowczewskie F, Rudner C, Enneking WF. Freeze-dried allogeneic segmental cortical-bone grafts in dogs. J Bone Joint Surg $[\mathrm{Am}] 1978 ; 60-\mathrm{A}: 1082-90$.
Burwell RG. The fate of bone grafts. In: Apley AG, ed. Recent advances in orthopaedics. London: J \& A Churchill, 1969;115-207.

Burwell RG. Further studies of composite homograft-autografts of cancellous bone after transplantation to a muscular site. $J$ Anat 1963;97:146-7.

Einhorn TA, Lane JM, Burstein AH, Kopman CR, Vigorita VJ. The healing of segmental bone defects induced by demineralized bone matrix. J Bone Joint Surg [Am] 1984;66-A:274-9.

Glowacki J, Altobelli D, Mulliken JB. Fate of mineralized and demineralized osseous implants in cranial defects. Calcif Tissue Int 1981; 33:71-6.

Goldberg VM, Bos GD, Heiple KG, Zika JM, Powell AE. Improved acceptance of frozen bone allografts in genetically mismatched dogs by immunosuppression. J Bone Joint Surg [Am] 1984;66-A: 937-50.

Heiple KG, Chase SW, Herndon CH. A comparative study of the healing process following different types of bone transplantation. $J$ Bone Joint Surg [AM] 1963:45 A : 1593 1616.

Key JA. The effect of a local calcium depot on osteogenesis and healing of fractures. J Bone Joint Surg [Am] 1934;16:176-84.

Lindholm TS, Urist MR. A quantitative analysis of new bone formation by induction in compositive grafts of bone marrow and bone matrix. Clin Orthop 1980;150:288-300.

Nathanson MA. Analysis of cartilage differentiation from skeletal muscle grown on bone matrix. III. Environmental regulation of glycosaminoglycan and proteoglycan synthesis. Dev Biol 1983;96:
46-62.

Nathanson MA, Hay EC. Analysis of cartilage differentiation from skeletal muscle grown on bone matrix. I. Ultrastructural aspects. Dev Biol 1980; 78: 301-31.

Nathanson MA, Hilfer SA, Searls RL. Formation of cartilage by nonchondrogenic cell types. Dev Biol 1978;64:99-117.

Takagi K, Urist MR. The role of bone marrow in bone morphogenetic protein-induced repair of femoral massive diaphyseal defects. Clin Orthop 1982:171:224 31 .

Tavassoli M, Yofiey JM. Bone marron: structure and function. New York: Alan R Liss, 1983.

Urist MR, Hudak RT. Radioimmunoassay of bone morphogenetic protein in serum: a tissue-specific parameter of bone metabolism (41900). Proc Soc Exp Biol Med 1984;176:472-5.

Urist MR, Jurist JM Jr, Dubuc FL, Strates BS. Quantitation of new bone formation in intramuscular implants of bone matrix in rabbits. Clin Orthop 1970;68:279-93.

Urist MR, Lietze A, Mizutani H, et al. A bovine low molecular weight bone morphogenetic protein (BMP) fraction. Clin Orthop 1982; 162:219-32.

Urist MR, Delange RJ, Finerman GAM. Bone cell differentiation and growth factors. Science 1983:220:680-6.

Urist MR, Huo YK, Brownell AB, et al. Purification of bovine bone morphogenetic protein by hydroxyapatite chromatography. Proc Nat Acad Sci USA 1984;81:371-5.

Urist MR, Hudak R, Huo Y-K, Rasmussen J, Hirota W, Lietze A. Bone morphogenetic protein (BMP) and anti-BMP immunoassay in patients with osteoporosis. In: Butler WT, ed. The chemistry and biology of mineralized tissues. Proceedings of the second international conference held in Alabama 1984. Birmingham, Alabama: Ebsco Media, 1985:62 9.

Velasco RU, Habal MB, Spiegel PG, Lotz M, Leake DL. A study of autologous cancellous bone particles in long bone discontinuity defects. Clin Orthop 1983;177:264-73.

Wittbjer J, Palmer B, Rohlin M, Thorngren K-G. Osteogenetic activity in composite grafts of demineralized compact bone and marrow. Clin Orthop 1983;173:229-38. 